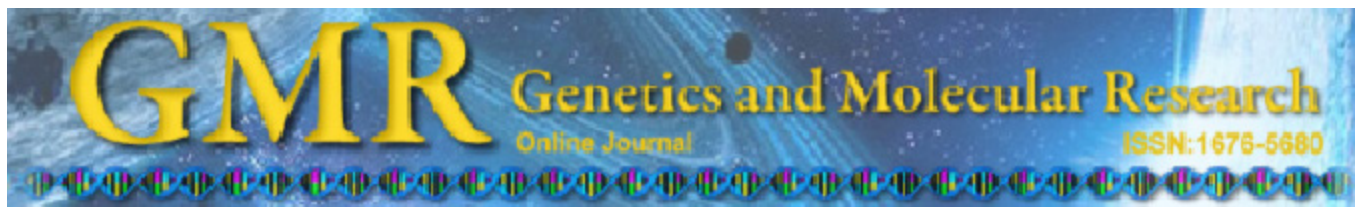

\title{
Egg laying and egg quality in meat type quails in diallel crosses
}

\author{
E.C.S. Drumond, A.V. Pires, C.M. Bonafé, S.R.F. Pinheiro, R.C. Veloso, \\ J.M. Amaral and L.R.A. Abreu \\ Departamento de Zootecnia, \\ Universidade Federal dos Vales do Jequitinhonha e Mucuri, \\ Diamantina, MG, Brasil \\ Corresponding author: R.C. Veloso \\ E-mail: velosozootecnista@yahoo.com.br
}

Genet. Mol. Res. 13 (4): 8118-8125 (2014)

Received July 26, 2013

Accepted February 3, 2014

Published October 7, 2014

DOI http://dx.doi.org/10.4238/2014.October.7.6

\begin{abstract}
This study aimed to assess egg laying and egg quality in quail lines in diallel crosses. We evaluated 16 genetic groups obtained from crosses of four strains of meat quails (L1, L2, L3, and L4) in a complete diallel. We assessed weekly egg number (WEN), egg yield (EY), egg weight (EW), and Haugh unit (HU) for: 51-80, 81-110, 111140 , and 51-140 days (whole period) old. The general combining capacity (GCC) showed significance for WEN and EY, with the exception of the period of 111-140 days. In general, L3 had the highest positive GCC estimates. The additive genetic variability was significant for EW in all periods, as was HU, with the exception of the first period. The specific combining capacity was significant for $\mathrm{HU}$, except in the second period. The largest estimates for GCC were submitted by L1 for EW, followed by L4, considering the whole period. For HU, L2 had the highest estimates for GCC. The more favorable cross for HU was L2xL3, in the whole period. In the third period, there was a significant reciprocal effect, where there was a positive estimate for the cross L2xL3.
\end{abstract}

Key words: Combining ability; Egg production; Haugh unit 


\section{INTRODUCTION}

The production of quail eggs increased by $20.8 \%$ in 2010 compared to the previous year, with 232.398 million dozen produced (IBGE, 2010).

However, eggs for incubation must be constantly evaluated and rigorously chosen; eggs outside quality standards must be rejected (Albino and Barreto, 2003).

As such, the evaluation of the production and quality of meat quail eggs is of fundamental importance for the breeding; genetic differences between the strains may change the eggs' internal and external quality, as well as their production.

However, the identification of superior genotypes and the establishment of guidelines for mating are not always simple tasks. To make efficient use of crosses, the application of developed strains for development of hybrids must be oriented on the basis of results obtained in diallel crosses (Griffing, 1956), which have been used to express a set of $p(p-1) / 2$ hybrids, resulting from the mating of progenitors and/or other related generations (Cruz and Regazzi, 2001).

Through this practice, it is possible to estimate the general combining capacity (GCC), which indicates the level of each line in terms of additive genetic effects, specific combining capacity (SCC), which indicates the level of heterosis in each cross, and reciprocal effect, which determines the most adequate use of the strains' sex in crosses.

The objective of this study was to evaluate the production of eggs and the quality of meat quails through diallel crosses.

\section{MATERIAL AND METHODS}

This study was carried out at the facilities of the "Programa de Melhoramento Genético de Codornas" of the Departamento de Zootecnia at Universidade Federal dos Vales do Jequitinhonha e Mucuri (UFVJM), from February to May 2012.

Four strains of meat quails, designated L1, L2, L3, and L4, were evaluated in diallel crosses, providing 16 groups of progeny - four pure, six mixed F1 and six mixed F1 reciprocal, in a completely randomized experiment, with three repetitions of five females per experimental unit, for a total of 240 animals.

Free water was provided through nipple drinkers, and the feed containing $20 \% \mathrm{CP}$, $2900 \mathrm{kcal} \mathrm{ME} / \mathrm{kg}$ and 3.2\% Ca (NRC, 1994) was also provided freely in gutter-type feeders. The lighting program provided 17 hours of light per day until the end of the experimental period.

Data collection was divided into three periods: P1 (51- to 80-day-old poultry), P2 (81to 110-day-old), and P3 (111- to 140-day-old), to cover the pre-apex period, the apex period, and the laying post-apex, respectively. The total period was evaluated as well, TP (51 to 140 days). We determined egg weight (EW), Haugh unit (HU), average number of eggs per week per quail (WEN) and average percentage of laying per week per quail (EY).

$\mathrm{HU}$ was obtained through a logarithmic ratio between egg weight ( $\mathrm{g}$ ) and albumen height (mm), according to the formula proposed by Haugh (1937):

$$
U H=100 \log \left(H+7.57-1.7 W^{0.37}\right) \quad \text { (Equation 1) }
$$


where $H$ is the albumen height ( $\mathrm{mm}$ ) and $W$ is the egg weight (g).

The eggs were weighed using a precision balance and the albumen height measured with a digital pachymeter. The eggs for weight analysis and HU were collected on the 15th and 16th days of each period, and the analysis was performed on the collection day.

EY was calculated as the ratio between WEN and the number of quails, expressed as percentage.

The diallel analysis was carried out in a univariate way, considering the methodology of complete diallels, including the $\mathrm{p}^{2}$ combinations, using Griffing method 1 (1956), described by Cruz and Regazzi (2001), from the averages of genotypic combinations resulting from the three repetitions of five poultry each. The statistical model used was:

$$
Y_{i j}=\mu+g_{i}+g_{j}+s_{i j}+r_{i j}+\varepsilon_{i j}
$$

where $Y_{i j}$ is the average value of the hybrid combination $(i \neq j)$ or the progenitor $(i=j) ; \mu$ is the overall average; $g_{i}, g_{j}$ are the effect of the overall combining capacity of the progenitor (i, $\mathrm{j}=1,2,3$ and 4$) ; s_{i j}$ is the effect of the SCC for the crosses between the progenitors of order $\mathrm{i}$ and $\mathrm{j} ; r_{i j}$ is the reciprocal effect that measures the differences provided by progenitor $\mathrm{i}$ or $\mathrm{j}$, when used as female (i) or male ( $\mathrm{j}$ ) in the $\mathrm{ij}$ cross; $\varepsilon_{i j}$ is the experimental error associated with the observation of $\mathrm{ij}$ order. Considered in this model are $s_{i j}=s_{j i}, r_{i j}$ $=-\mathrm{r}_{\mathrm{ji}}$ and $\mathrm{r}_{\mathrm{ii}}=0$.

For the estimation of the overall and specific capacity of the reciprocal effects and their respective sums of squares, we chose the method of least squares using the linear model, with the restrictions presented by Cruz and Regazzi (2001) being adopted.

The significance of the effects of the factors included in the model was determined according to the F test, by means of the GENES software (Cruz, 2006).

\section{RESULTS AND DISCUSSION}

The number of eggs per week per quail in the periods evaluated (Table 1) showed overall averages of 6.2 (P1), $6.65(\mathrm{P} 2), 6.55$ (P3), and 6.46 (TP). The averages for the laying percentage were $88.4 \%(\mathrm{P} 1), 95.13 \%(\mathrm{P} 2), 93.58 \%(\mathrm{P} 3)$, and $92.38 \%(\mathrm{TP})$.

$\mathrm{EW}$ is important due to its high correlation with the weight of the quails at birth, which, in turn, can determine the poultry final weight. In this study, the general averages of EW were 13.57, 13.76, 13.90, and 13.75 (Table 2) and were slightly superior to those found by Móri et al. (2005), whose average, evaluating four genetic groups of meat quails, was 13.12 .

In general, the higher the $\mathrm{HU}$ value, the better the egg internal quality is (Alleoni and Antunes, 2001). The HU general averages for the periods were 97.50 (P1), 92.07 (P2), 94.36 (P3), and 94.64 (TP) (Table 2), and were similar to those reported by Murakami et al. (2006), with a general average of 93.73 and superior to those reported by Moura et al. (2008), with an average of 85.08. However, both used Japanese quails. 


\begin{tabular}{|c|c|c|c|c|c|c|c|}
\hline \multirow[t]{2}{*}{ Characteristic } & \multirow[t]{2}{*}{ Female } & \multicolumn{4}{|c|}{ Male } & \multirow[t]{2}{*}{ Average } & \multirow[t]{2}{*}{$\mathrm{CV}(\%$} \\
\hline & & $\mathrm{L} 1$ & L2 & L3 & L4 & & \\
\hline \multirow[t]{4}{*}{ WEN80 (51 to 80 days) } & L1 & 5.6 & 6.3 & 6.2 & 6.2 & 6.0 & \multirow[t]{5}{*}{8.31} \\
\hline & L2 & 6.1 & 6.2 & 6.5 & 6.0 & 6.2 & \\
\hline & L3 & 6.1 & 6.4 & 6.7 & 6.8 & 6.5 & \\
\hline & L4 & 5.8 & 5.9 & 6.9 & 5.6 & 6.0 & \\
\hline Average & & 5.9 & 6.2 & 6.5 & 6.1 & 6.2 & \\
\hline \multirow[t]{4}{*}{ WEN110 (81 to 110 days) } & L1 & 6.7 & 6.8 & 6.8 & 6.9 & 6.8 & \multirow[t]{4}{*}{5.07} \\
\hline & L2 & 6.7 & 6.2 & 6.2 & 6.4 & 6.3 & \\
\hline & L3 & 6.6 & 6.9 & 6.7 & 6.8 & 6.7 & \\
\hline & L4 & 6.9 & 6.3 & 6.8 & 6.8 & 6.7 & \\
\hline Average & & 6.7 & 6.5 & 6.6 & 6.7 & 6.6 & \\
\hline \multirow[t]{4}{*}{ WEN140 (111 to 140 days) } & $\mathrm{L} 1$ & 6.8 & 6.7 & 6.9 & 6.9 & 6.8 & \multirow[t]{4}{*}{7.42} \\
\hline & L2 & 6.2 & 6.3 & 6.2 & 6.1 & 6.2 & \\
\hline & L3 & 6.3 & 6.8 & 6.6 & 7.0 & 6.6 & \\
\hline & L4 & 6.6 & 6.1 & 6.8 & 6.5 & 6.5 & \\
\hline Average & & 6.4 & 6.4 & 6.6 & 6.6 & 6.5 & \multirow{5}{*}{4.65} \\
\hline \multirow[t]{4}{*}{ WENT ( 51 to 140 days) } & $\mathrm{L} 1$ & 6.4 & 6.6 & 6.6 & 6.6 & 6.5 & \\
\hline & L2 & 6.3 & 6.2 & 6.3 & 6.2 & 6.2 & \\
\hline & L3 & 6.3 & 6.7 & 6.7 & 6.8 & 6.6 & \\
\hline & L4 & 6.4 & 6.1 & 6.9 & 6.3 & 6.4 & \\
\hline Average & & 6.3 & 6.4 & 6.6 & 6.4 & 6.5 & \\
\hline \multirow{4}{*}{ EY80 (51 to 80 days) } & $\mathrm{L} 1$ & 79.6 & 89.9 & 87.7 & 88.0 & 86.3 & \multirow[t]{4}{*}{8.38} \\
\hline & L2 & 87.2 & 89.4 & 92.5 & 85.7 & 88.7 & \\
\hline & L3 & 86.5 & 91.6 & 95.7 & 96.5 & 92.5 & \\
\hline & L4 & 82.4 & 84.1 & 98.4 & 79.2 & 86.0 & \\
\hline Average & & 83.9 & 88.7 & 93.5 & 87.3 & 88.4 & \\
\hline \multirow[t]{4}{*}{ EY110 (81 to 110 days) } & L1 & 96.4 & 97.2 & 97.3 & 98.1 & 97.2 & \multirow[t]{4}{*}{5.01} \\
\hline & L2 & 95.6 & 88.6 & 88.8 & 92.0 & 91.2 & \\
\hline & L3 & 94.0 & 98.5 & 95.6 & 96.9 & 96.2 & \\
\hline & L4 & 98.1 & 90.7 & 97.6 & 96.8 & 95.8 & \\
\hline Average & & 96.0 & 93.7 & 94.8 & 95.9 & 95.4 & \\
\hline \multirow[t]{4}{*}{ EY140 (111 to 140 days) } & L1 & 97.5 & 95.7 & 98.1 & 98.3 & 97.4 & \multirow[t]{4}{*}{7.44} \\
\hline & L2 & 88.8 & 89.9 & 88.7 & 86.9 & 88.5 & \\
\hline & L3 & 89.4 & 97.8 & 95.0 & 99.3 & 95.3 & \\
\hline & L4 & 93.9 & 87.3 & 97.3 & 93.5 & 93.0 & \\
\hline Average & & 92.4 & 92.6 & 94.7 & 94.5 & 93.6 & \\
\hline \multirow[t]{4}{*}{ EYT (51 to 140 days) } & L1 & 91.1 & 94.3 & 94.4 & 94.8 & 93.6 & \multirow[t]{5}{*}{4.64} \\
\hline & L2 & 90.5 & 89.3 & 90.0 & 88.2 & 89.5 & \\
\hline & L3 & 90.0 & 96.0 & 95.4 & 97.6 & 94.7 & \\
\hline & L4 & 91.5 & 87.4 & 97.8 & 89.8 & 91.6 & \\
\hline Average & & 90.7 & 91.7 & 94.4 & 92.6 & 92.4 & \\
\hline
\end{tabular}

$\mathrm{CV}=$ coefficient of variation.

The crossing between L2 females and L1 males showed the highest average for EW (14.36 g) and HU (97.59) in the total period. Also important were the crossings between L2 females and L3 males for HU (97.20), and the L4xL1 and L1xL2 crossings with EW of 14.30 $\mathrm{g}$, considering the total period.

The GCC was significant for WEN and EY in almost every period evaluated, with the exception of the third period (Table 3). Considering the results of this study, these characteristics were shown to have an additive effect, which was of great importance to their manifestation. Therefore, substantial gains can be achieved through intrapopulation selection. 


\begin{tabular}{|c|c|c|c|c|c|c|c|}
\hline Characteristic & $\mathrm{F} / \mathrm{M}$ & L1 & L2 & L3 & L4 & Average & CV $(\%)$ \\
\hline \multirow{4}{*}{ EW80 (g) (51 to 80 days) } & L1 & 13.90 & 14.78 & 13.38 & 13.68 & 13.93 & \multirow[t]{4}{*}{4.56} \\
\hline & L2 & 14.16 & 13.63 & 12.79 & 13.59 & 13.54 & \\
\hline & L3 & 13.50 & 13.50 & 12.56 & 13.61 & 13.29 & \\
\hline & L4 & 13.98 & 13.19 & 13.14 & 13.78 & 13.52 & \\
\hline Average & & 13.88 & 13.77 & 12.96 & 13.66 & 13.57 & \multirow{5}{*}{3.70} \\
\hline \multirow[t]{4}{*}{ EW110 (g) (81 to 110 days) } & L1 & 14.41 & 14.27 & 13.48 & 13.65 & 13.95 & \\
\hline & L2 & 14.32 & 13.40 & 13.49 & 13.35 & 13.64 & \\
\hline & L3 & 14.00 & 13.84 & 13.33 & 13.50 & 13.66 & \\
\hline & L4 & 14.01 & 14.01 & 13.10 & 14.13 & 13.81 & \\
\hline Average & & 14.18 & 13.88 & 13.35 & 13.65 & 13.76 & \\
\hline \multirow[t]{4}{*}{ EW140 (g) (111 to 140 days) } & L1 & 14.25 & 13.85 & 13.57 & 14.50 & 14.04 & \multirow[t]{4}{*}{4.65} \\
\hline & L2 & 14.59 & 13.74 & 12.88 & 13.98 & 13.79 & \\
\hline & L3 & 14.07 & 13.42 & 12.90 & 13.53 & 13.48 & \\
\hline & L4 & 14.47 & 14.29 & 13.79 & 14.72 & 14.31 & \\
\hline Average & & 14.34 & 13.82 & 13.28 & 14.18 & 13.90 & \\
\hline \multirow[t]{4}{*}{ EWT (g) (51 to 140 days) } & L1 & 14.19 & 14.30 & 13.48 & 13.94 & 13.97 & \multirow[t]{4}{*}{3.04} \\
\hline & L2 & 14.36 & 13.59 & 13.05 & 13.64 & 13.66 & \\
\hline & L3 & 13.86 & 13.59 & 12.93 & 13.55 & 13.48 & \\
\hline & L4 & 14.30 & 13.83 & 13.34 & 14.21 & 13.92 & \\
\hline Average & & 14.17 & 13.82 & 13.20 & 13.83 & 13.75 & \\
\hline \multirow[t]{4}{*}{ HU80 (51 to 80 days) } & L1 & 93.45 & 99.19 & 97.15 & 99.00 & 97.19 & \multirow[t]{4}{*}{2.69} \\
\hline & L2 & 101.84 & 97.00 & 101.75 & 95.27 & 98.96 & \\
\hline & L3 & 96.81 & 97.92 & 96.55 & 94.55 & 96.45 & \\
\hline & L4 & 96.14 & 99.48 & 98.71 & 95.28 & 97.40 & \\
\hline Average & & 97.06 & 98.39 & 98.54 & 96.02 & 97.50 & \\
\hline \multirow{4}{*}{ HU110 (81 to 110 days) } & $\mathrm{L} 1$ & 91.18 & 94.07 & 92.68 & 93.95 & 92.97 & \multirow[t]{4}{*}{2.32} \\
\hline & L2 & 93.55 & 92.24 & 90.83 & 92.20 & 92.20 & \\
\hline & L3 & 91.72 & 93.93 & 88.69 & 92.06 & 91.60 & \\
\hline & L4 & 92.69 & 93.29 & 91.02 & 89.11 & 91.52 & \\
\hline Average & & 92.28 & 93.38 & 90.80 & 91.83 & 92.07 & \\
\hline \multirow{4}{*}{ HU140 (111 to 140 days) } & L1 & 91.40 & 92.19 & 94.17 & 94.11 & 92.96 & \multirow[t]{4}{*}{2.22} \\
\hline & L2 & 97.40 & 99.35 & 99.02 & 98.49 & 98.56 & \\
\hline & L3 & 96.86 & 96.22 & 88.22 & 91.61 & 93.22 & \\
\hline & L4 & 93.88 & 94.28 & 92.27 & 90.35 & 92.69 & \\
\hline Average & & 94.88 & 95.51 & 93.42 & 93.64 & 94.36 & \multirow{6}{*}{1.72} \\
\hline \multirow[t]{4}{*}{ HUT (51 to 140 days) } & $\mathrm{L} 1$ & 92.01 & 95.15 & 94.67 & 95.68 & 94.37 & \\
\hline & L2 & 97.59 & 96.20 & 97.20 & 95.32 & 96.57 & \\
\hline & L3 & 95.13 & 96.02 & 91.15 & 92.74 & 93.76 & \\
\hline & L4 & 94.23 & 95.69 & 94.00 & 91.58 & 93.87 & \\
\hline Average & & 94.74 & 95.76 & 94.25 & 93.83 & 94.64 & \\
\hline
\end{tabular}

$\mathrm{CV}=$ coefficient of variation.

Table 3. Summary of the analysis of the general combining capacity (GCC), specific combining capacity (SCC), and reciprocal effect (RE) for number of eggs per week per quail (WEN) and percentage of laying in the week (EY) in meat quails, in the four periods of evaluation.

\begin{tabular}{lrlccccccc}
\hline Source of variation & d.f. & \multicolumn{9}{c}{ Average square } \\
\cline { 3 - 9 } & & WEN80 & EY80 & WEN110 & EY110 & WEN140 & EY140 & WEN & EYT \\
\hline Treatment & 15 & 0.45 & 95.75 & 0.18 & 33.09 & 0.29 & 58.16 & 0.17 \\
GCC & 3 & $1.35^{* *}$ & $285.61^{* *}$ & $0.42^{*}$ & $79.28^{*}$ & 0.52 & 101.90 & $0.36^{* *}$ & 63.63 \\
SCC & 6 & 0.39 & 84.81 & 0.10 & 15.67 & 0.18 & 37.04 & 0.14 & 31.75 \\
RE & 6 & 0.26 & 11.77 & 0.04 & 27.43 & 0.27 & 57.41 & 0.10 & 20.34 \\
Waste & 32 & 0.26 & 54.93 & 0.04 & 22.79 & 0.23 & 48.53 & 0.09 & 18.39 \\
\hline
\end{tabular}

$* \mathrm{P}<0.05$ and $* * \mathrm{P}<0.01$ significant by the $\mathrm{F}$ test, to 5 and $1 \%$, respectively. 
For the WEN and EY, the SCC did not show any significance in any period evaluated, nor did it show its reciprocal effect, demonstrating the reduced influence of the non-additive effects (dominance or epistasis). Also, there was no influence of sex as a determinant effect on crossing (Table 3), showing that, for the lines studied, any of them could be used as a male or a female line.

The additive genetic variability was significant also for EW in all periods evaluated, the same way it was for HU, with the exception of the first period on the latter (Table 4). Thus, the choice of genetically superior progenitors within pure lines is viable and can provide satisfactory gains.

$\begin{aligned} & \text { Table 4. Summary of the analysis of the general combining capacity (GCC), specific combining capacity (SCC), } \\
& \text { and reciprocal effect (RE) for egg weight (EW) and Haugh unit (HU) for meat quails in four periods of evaluation. }\end{aligned}$
\begin{tabular}{lccccccccc}
\hline Source of variation & d.f. & \multicolumn{7}{c}{ Average square } \\
\cline { 2 - 9 } & & EW80 & EW110 & EW140 & EWT & HU80 & HU110 & HU140 & HUT \\
\hline Treatment & 15 & $0.83^{*}$ & $0.57^{*}$ & $0.94^{*}$ & $0.59^{* *}$ & $17.23^{*}$ & 7.84 & $32.43^{* *}$ & $11.08^{* *}$ \\
GCC & 3 & $2.54^{* *}$ & $1.53^{* *}$ & $3.87^{* *}$ & $2.32^{* *}$ & 17.21 & $13.9^{*}$ & $78.82^{* *}$ & $26.97^{* *}$ \\
SCC & 6 & 0.46 & 0.25 & 0.09 & 0.14 & $18.22^{*}$ & 8.98 & $26.55^{* *}$ & $11.36^{* * *}$ \\
RE & 6 & 0.34 & 0.40 & 0.31 & 0.16 & 16.25 & 3.66 & $15.11^{* *}$ & 2.84 \\
Waste & 32 & 0.38 & 0.26 & 0.42 & 0.17 & 6.91 & 4.55 & 4.37 & 2.64 \\
\hline
\end{tabular}

$* \mathrm{P}<0.05$ and $* * \mathrm{P}<0.01$ significant by the $\mathrm{F}$ test.

The SCC, which represents the influence of the non-additive genetic effects, was significant only for $\mathrm{HU}$, with the exception of the second period, allowing the identification of superior hybrid combinations for this characteristic (Table 4).

Overall, L3 showed the highest positive estimates of GCC, where it was the most indicated for increasing the production of eggs and laying percentage, independently of the crosses in which it participated. It showed higher precocity in the production of eggs and higher total production, although it did show lower estimates in the laying peak (WEN110 and EY110) than in the strains L1 and L4. L2 displayed the worst performance among the strains evaluated, with negative estimates of GCC in all the periods evaluated, except for EY80 (Table 5).

Table 5. General combining capacity $\left(\hat{\mathrm{g}}_{\mathrm{i}}\right)$ to number of eggs per week (WEN) and percentage of laying per week (EY) in meat quails, in the four periods of evaluation.

\begin{tabular}{|c|c|c|c|c|c|c|c|c|}
\hline Lineage & WEN80 & EY80 & WEN110 & EY110 & WEN140 & EY140 & WENT & EYT \\
\hline$\hat{\mathrm{g}}_{\mathrm{i}}(\mathrm{L} 1)$ & -0.219 & -3.29 & 0.106 & 1.50 & 0.100 & 1.31 & -0.012 & -0.17 \\
\hline$\hat{\mathrm{g}}_{\mathrm{i}}(\mathrm{L} 2)$ & -0.006 & 0.32 & -0.194 & -2.64 & -0.212 & -2.96 & -0.137 & -1.76 \\
\hline$\hat{\mathrm{g}}_{\mathrm{i}}(\mathrm{L} 3)$ & 0.331 & 4.67 & 0.031 & 0.40 & 0.100 & 1.49 & 0.162 & 2.19 \\
\hline$\hat{\mathrm{g}}_{\mathrm{i}}$ (L4) & -0.106 & -1.71 & 0.056 & 0.74 & 0.012 & 0.16 & -0.012 & -0.27 \\
\hline
\end{tabular}

On the basis of general combining capacity, the highest estimates for EW were shown by L1, followed by L4, which showed positive estimate considering the total evaluated period. On the other hand, L3 had the worst performance for this characteristic, and was, therefore, not indicated for crosses aimed at increasing egg weight. For HU, L2 showed the highest estimates, with higher internal quality of eggs, while L1 had positive estimates only in the second period (Table 6). Aiming at reaching base populations, L3 could be used for the female line, while L1 or L2 could be used to for the male line. 
Table 6. General combining capacity $\left(\hat{g}_{\mathrm{i}}\right)$ to egg weight $(\mathrm{EW})$ and Haugh unit (HU) for meat quails, in the four periods of evaluation.

\begin{tabular}{|c|c|c|c|c|c|c|c|c|}
\hline Lineage & EW80 & EW110 & EW140 & EWT & HU80 & HU110 & HU140 & HUT \\
\hline$\hat{\mathrm{g}}_{\mathrm{i}}(\mathrm{L} 1)$ & 0.3369 & 0.3281 & 0.2844 & 0.3175 & -0.3769 & 0.5519 & -0.4375 & -0.0887 \\
\hline$\hat{\mathrm{g}}_{\mathrm{i}}(\mathrm{L} 2)$ & 0.0856 & -0.0356 & -0.0981 & -0.0162 & 1.1756 & 0.7181 & 2.6737 & 1.5237 \\
\hline$\hat{\mathrm{g}}_{\mathrm{i}}(\mathrm{L} 3)$ & -0.4431 & -0.2869 & -0.5269 & -0.4187 & -0.0069 & -0.8731 & -1.0400 & -0.6400 \\
\hline$\hat{\mathrm{g}}_{\mathrm{i}}(\mathrm{L} 4)$ & 0.0206 & -0.0056 & 0.3406 & 0.1175 & -0.7919 & -0.3969 & -1.1962 & -0.7950 \\
\hline
\end{tabular}

The SCC was not significant for the WEN, EY and EW characteristics in the periods evaluated, indicating that there was no cross with superior performance that could lead to substantial gains in these characteristics.

The best hybrid combinations are those with higher estimates of SCC $\left(\hat{\mathrm{s}}_{\mathrm{ij}}\right)$. Thus, the most favorable crosses for $\mathrm{HU}$, in the first period (51 to 80 days), were L1xL2 or L2xL3. For the third period and the total period, the indicated cross was L2xL3 (Table 7).

\begin{tabular}{|c|c|c|c|c|c|}
\hline \multirow[t]{2}{*}{ Characteristic } & \multirow[t]{2}{*}{ Female } & \multicolumn{4}{|c|}{ Male } \\
\hline & & L1 & L2 & L3 & L4 \\
\hline \multirow[t]{4}{*}{ HU80 (51 to 80 days) } & L1 & -3.30 & 2.21 & -0.14 & 1.23 \\
\hline & L2 & -1.32 & -2.85 & 1.16 & -0.51 \\
\hline & L3 & 0.17 & 1.91 & -0.94 & -0.07 \\
\hline & L4 & 1.43 & -2.10 & -2.08 & -0.64 \\
\hline \multirow[t]{4}{*}{ HU110 (81 to 110 days) } & $\mathrm{L} 1$ & -1.99 & 0.46 & 0.44 & 1.08 \\
\hline & L2 & 0.26 & -1.27 & 0.45 & 0.34 \\
\hline & L3 & 0.48 & -1.55 & -1.63 & 0.73 \\
\hline & L4 & 0.63 & -0.54 & 0.52 & -2.17 \\
\hline \multirow[t]{4}{*}{ HU140 (111 to 140 days) } & L1 & -2.08 & -1.80 & 2.62 & 1.26 \\
\hline & L2 & -2.60 & -0.36 & 1.62 & 0.54 \\
\hline & L3 & -1.34 & 1.40 & -4.06 & -0.18 \\
\hline & L4 & 0.11 & 2.10 & -0.33 & -1.62 \\
\hline \multirow[t]{4}{*}{ HUT (51 to 140 days) } & L1 & -2.46 & 0.28 & 0.98 & 1.19 \\
\hline & L2 & -1.22 & -1.49 & 1.07 & 0.12 \\
\hline & L3 & -0.23 & 0.59 & -2.21 & 0.15 \\
\hline & L4 & 0.72 & -0.18 & -0.63 & -1.47 \\
\hline
\end{tabular}

For HU, there was a significant effect on reciprocal cross effect $\left(\hat{r}_{\mathrm{ij}}\right)$ in the third period, where a positive estimate was observed for the L2xL3 cross, and since the progenitor i concerned the female strain, the mating of L2 females with L3 males, for this period, would be more indicated, although there was no influence of sex in the total period.

\section{CONCLUSION}

There was a greater influence of the additive effect genes on laying characteristics and on EW. Aimed at higher egg production, the crosses of L3 can result in satisfactory gains; considering EW, the strains L1 and L4 can increase the characteristic; considering HU, the L2xL3 cross is the most indicated. 


\title{
ACKNOWLEDGMENTS
}

\author{
Research supported by CAPES, CNPq and Fapemig.
}

\section{REFERENCES}

Albino LFT and Barreto SLT (2003). Criação de Codornas para Produção de Ovos e Carne. Editora Aprenda Fácil, Viçosa.

Alleoni CC and Antunes AJ (2001). Haugh unit as a measure of the quality of hen eggs stored under refrigeration. Sci. Agr. 58: 681-685.

Cruz CD (2006). Programa Genes: Biometria. Editora UFV, Viçosa.

Cruz CD and Regazzi AJ (2001). Modelos Biométricos Aplicados ao Melhoramento Genético. 2nd edn. Imprensa Universitária, Viçosa.

Griffing B (1956). Concept of general and specific combining ability in relation to diallel crossing systems. Aust. J. Biol. Sci. 9: 463-493.

Haugh RR (1937). The Haugh unit for measuring egg quality. United States Egg Poultry Magazine 43: $552-555$.

IBGE - Instituto Brasileiro de Geografia e Estatística (2010). Produção da Pecuária Municipal, 1-66.

Moura AMA, Oliveira NTE, Thiebaut JTL and Melo TV (2008). Effect of storage temperature and type of package on the internal quality of eggs from Japanese quails (Coturnix japonica). Cienc. Agrotóxicos Lav. 32: 578-583.

Móri C, Garcia EA, Pavan AC, Piccinin A, et al. (2005). Performance and egg quality of four quail genetic groups. Rev. Bras. Zoot. 34: 864-869.

Murakami AE, Sakamoto MI and Souza LMG (2006). Determination of the best level of salt for Japanese laying quails. Rev. Bras. Zoot. 35: 2333-2337.

National Research Council - NRC (1994). Nutrient Requirements of Poultry. Washington, 44-45. 